University of Nebraska - Lincoln

DigitalCommons@University of Nebraska - Lincoln

$3-2002$

\title{
A New Urgency About Anthrax: Recent Efforts to Prevent the Proliferation of Biological Weapons in the Former Soviet Union
}

Jack M. Beard

University of Nebraska College of Law, jbeard2@unl.edu

Follow this and additional works at: https://digitalcommons.unl.edu/lawfacpub

Beard, Jack M., "A New Urgency About Anthrax: Recent Efforts to Prevent the Proliferation of Biological Weapons in the Former Soviet Union" (2002). College of Law, Faculty Publications. 161.

https://digitalcommons.unl.edu/lawfacpub/161

This Article is brought to you for free and open access by the Law, College of at DigitalCommons@University of Nebraska - Lincoln. It has been accepted for inclusion in College of Law, Faculty Publications by an authorized administrator of DigitalCommons@University of Nebraska - Lincoln. 


\title{
A NeW URGency ABOUt ANTHRAX: Recent EfForts to Prevent the Proliferation OF BIOLOGICAL WEAPONS IN THE FORMER SOVIET UNION
}

\author{
by Jack M. Beard*
}

The threat of biological weapons, once an obscure topic to most Americans, achieved new prominence and urgency in the United States with the anthrax letter attacks that followed the terrorist attacks of September 11, 2001. A number of infections traced to a handful of anthrax-laced letters focused unprecedented attention in America on the danger of biological weapons (BW). Coupled with continuing reports of attempts by terrorists to acquire weapons of mass destruction, this has made efforts to prevent BW proliferation a high priority for the U.S. government.

Notwithstanding the new prominence of the BW threat, the U.S. government recently withdrew its support of a seven-year effort to create a new protocol to improve monitoring and inspections under the 1972 Biological Weapons Convention (BWC).' Concerned that the protocol's approach would compromise sensitive biological defense and confidential business information and would do nothing to increase compliance with the BWC, U.S. Under Secretary of State for Arms Control and International Security John Bolton, told a UN Conference on the Biological Weapons Convention that "the United States will simply not enter into agreements that allow rogue states or others to develop and deploy biological weapons," stating that the draft biological weapons protocol "is dead in our view and not to be resurrected." The United States also sought

\footnotetext{
${ }^{9}$ BARTLETT, supra note 1 , at 783 .

- Associate Deputy General Counsel (International Affairs), U.S. Department of Defense; Adjunct Professor of Law, Georgetown University Law Center; Professorial Lecturer in International Law and Institutions, Paul H. Nitze School of Advanced International Studies, Johns Hopkins University. The views presented are those of the author and do not reflect the official policy or position of the Department of Defense or the U.S. government.

${ }^{1}$ Convention on the Prohibition of the Development, Production and Stockpiling of Bacteriological (Biological) and Toxin Weapons and on Their Destruction, Apr. 10, 1972, 26 UST 583, 1015 UNTS 163 (entered into force March 26, 1975) [hereinafter BWC] (there are currently 144 states that are parties to the BWC).

${ }^{2}$ John Zarocostas, U.S. Names Five Biological Weapons States, UNITEd PrESS INT'L, Nov. 19, 2001; Steven Mufson, U.S. Says Iraq, Others Pursue Germ Warfare, WASH. POST, Nov. 20, 2001, at A8 (noting that Mr. Bolton also said that "the time for 'better than nothing' protocols is over" and that "we will continue to reject flawed texts like the BWC draft protocol, recommended to us simply because they are the product of lengthy negotiations or arbitrary deadlines, if such texts are not in the best interests of the United States").
} 
to focus attention on the number of BWC member countries with offensive BW programs. In response, domestic and foreign commentators strongly criticized the U.S. position, questioning America's commitment to this and other multilateral efforts. ${ }^{3}$

Although the United States rejected the proposed BWC protocol, it continues to combat the threat posed by biological weapons by other means, including increased bilateral efforts to prevent the proliferation of biological weapons. In a recent meeting with the president of Russia, President Bush declared that "our highest priority is to keep terrorists from acquiring weapons of mass destruction" and that "we will strengthen our efforts to cut off every possible source of biological, chemical, and nuclear weapons, materials, and expertise." In this regard, there is no greater threat than that posed by the legacy of the Soviet Union's BW program. In addition to five military microbiological facilities under the control of the Soviet Ministry of Defense, it has been reported that as many as forty-seven other scientific institutes and production facilities worked on biological weapons under the cover of numerous other Soviet ministries and organizations. Many of these only recently came to light after Russian President Boris Yeltsin officially acknowledged the existence of an offensive BW program in April 1992. ${ }^{5}$

The legacy of the Soviet BW Program, coupled with economic problems in the states of the former Soviet Union (FSU), has posed a serious threat of proliferation of BWrelated expertise (the "brain drain" of former weapons scientists); smuggling or unauthorized transit of pathogenic agents; and export and diversion of BW-related equipment, including dual-use technology ${ }^{6}$ While many of the Soviet BW complexes and production centers were located in Russia, two other former Soviet states, Kazakhstan and Uzbekistan, also have inherited substantial portions of this deadly BW infrastructure. The Scientific Experimental and Production Base at Stepnogorsk, Kazakhstan has been called by experts the Soviet Union's main facility for the manufacture of biological weapons and was in fact "one of the largest installations ever created for this purpose. ${ }^{7}$ It was at Stepnogorsk that research teams developed the Soviet Union's most deadly weaponsgrade anthrax agents. Other facilities in Kazakhstan, such as the Scientific Research Agricultural Institute, developed agents harmful to livestock and plants. ${ }^{8} \mathrm{On}$ an isolated island named Vozrozhdeniye in the Aral Sea, the government of Uzbekistan is now confronted with the vast infrastructure that supported the Soviet Union's major open-air BW testing range. ${ }^{9}$ In addition to being the site for testing pathogens such as tularemia, $Q$-fever, brucellosis, glanders and the plague, Vozrozhdeniye is also the world's largest anthrax burial ground. ${ }^{10}$

'Bush Administration Irresponsible in Face of Bioweapons Threat: U.S. Kills Biological Weapons Conf., Puts U.S. at Risk, U.S. NEWSWIRE, Dec. 7, 2001 (noting that the U.S. position "so shocked delegates" that European Union representatives referred to the U.S. delegation as "liars"); Herve Kempf, Is US Power a Force for Good in the World? MANCHESTER GUARDIAN WKLY., Jan. 23, 2002, at 29 (arguing that U.S. actions such as the opposition to the biological weapons protocol show that "the Americans have adopted a deliberately unilateral stance").

${ }^{4}$ President's News Conference with President Vladimir Putin of Russia, Public PaPers of the Presidents, vol. 37, No. 46, Nov. 19, 2001, at 1.

${ }^{5}$ Jonathan B. Tucker, Bioweapons from Russia: Stemming the Flow, IsSUES IN SCI. \& TECH. ONLINE, Spring 1999, at 1-2, available at <http://www.nap.edu/issues>.

${ }^{6}$ Id. at 1 .

${ }^{7}$ Gulbarshyn Bozheyeva et al., Former Soviet Biological Weapons Facilities in Kazakhstan: Past, Present, Future, in 8 OCCASIONAL PAPER No. 1, at 8 (Monterey Inst., Center for Nonproliferation Stud., June 1999). The BW facilities at Stepnogorsk occupied two square kilometers and consisted of 25 buildings; they were capable of producing up to 300 metric tons of weapons-grade anthrax over a 10-month period.

Id. at 11 .

${ }^{9}$ Although both Kazakhstan and Uzbekistan own parts of Vozrozhdeniye Island, the BW-related infrastructure and testing range is located on the Uzbekistan portion of the island.

${ }^{10}$ Judith Miller, Poison Island: a Special Report; At Bleak Asian Site, Killer Germs Survive, N.Y. TIMES, June 2, 1999 , at Al. In the spring of 1988, Soviet scientists secretly transferred hundreds of tons of militarized anthrax bacteria in giant steel canisters to Vozrozhdeniye Island, where they were dumped into huge pits and only partially destroyed. 
U.S. government agencies are actively working to prevent the proliferation of BWrelated expertise in Russia, Kazakhstan, and Uzbekistan through a variety of mechanisms. For example, the Department of State has direct responsibility for several nonproliferation programs in these countries, helping establish or strengthen export control systems, providing better nonproliferation tools for export licensing and tracking, and overseeing U.S. participation in the International Science and Technology Center (ISTC) in Russia. ${ }^{11}$ The ISTC supports such activities as research projects that provide "incentives for weapons scientists to refrain from cooperating with terrorist groups or states" and redirects them to "sustainable careers in peaceful, transparent civilian endeavors." With numerous countries reportedly seeking former Soviet weapons scientists to further their own BW programs, ${ }^{13}$ these efforts to prevent the proliferation of BW-related expertise enjoy substantial U.S. government support.

The Department of Defense (DoD), through the Cooperative Threat Reduction (CTR) Program, is particularly active in what the DoD refers to as "Biological Weapons Proliferation Prevention" (BWPP) projects. These BWPP projects help FSU states dismantle former Soviet BW research and production facilities; consolidate, secure, and eliminate pathogenic stocks; and conduct targeted collaborative research with FSU scientists. As a DoD official stated in testimony before Congress, "in our view, the Biological Weapons Proliferation Prevention aspect of the CTR program is of exceptional, and increasing, importance."14

Under the auspices of the ISTC, the DoD is collaborating on research projects at numerous Russian facilities and is also active in projects that improve the physical security of dangerous pathogens and biological materials. Additional ISTC projects designed by the DoD to support BWPP objectives are planned. Besides sponsoring ISTC projects in Russia, the DoD is working closely with counterpart agencies on BWPP activities in Kazakhstan under an agreement concerning weapons of mass destruction infrastructure elimination (WMDIE Agreement).$^{15}$ These efforts include assistance in dismantling and demilitarizing BW facilities at Stepnogorsk, enhancing biological safety and security, and dismantling excess equipment and infrastructure at the Anti-Plague Institute in Almaty and the Scientific Research Agriculture Institute in Otar. Some of this assistance is provided under an annex to the WMDIE Agreement that is a framework for assistance related to "biological material protection, control, and accountability to conserve, characterize and protect strain collections of microorganisms and to prevent the proliferation of biological material that could contribute to the proliferation of weapons of mass destruction." 16

"Testimony of Vann Van Diepen, Deputy Assistant Secretary of State for Nonproliferation, Hearing Before the International Security, Proliferation and Federal Services Subcommittee of the Senate Governmental Affairs Committee on the Nonproliferation Assistance Coordination Act, FEDERAL NEWSSERVICE, Nov. 29, 2001. The ISTC, which began its work in 1994, is funded by private companies, the European Union, and the governments of Japan, Norway, Russia, South Korea, and the United States. A similar institution, the Science and Technology Center in Ukraine, began its work in 1995.

${ }^{12}$ Id.

${ }^{13}$ Judith Miller, The Germ Warriors: A Special Report; Iranians, Bioweapons in Mind, Lure Needy Ex-Soviet Scientists, N.Y. Times, Dec. 8, 1998, at A1.

${ }^{14}$ Prepared testimony of Marshall Billingslea, Deputy Assistant Secretary of Defense, Hearing Before the Senate Committee on Governmental Affairs Subcommittee on International Security, Proliferation and Federal Services on the Nonproliferation Assistance Coordination Act, FEDERAL NEWSSERVICE, Nov. 29, 2001.

${ }^{15}$ Agreement Between the Department of Defense of the United States of America and the Ministry of Energy, Industry, and Trade of the Republic of Kazakhstan Concerning the Elimination of Infrastructure for Weapons of Mass Destruction, Oct. 3, 1995, U.S.-Kaz., as amended June 10, 1996, Sept. 9, 1998, Dec. 17, 1999 , and July 29, 2000 (on file with author) [hereinafter WMDIE Agreement]. The WMDIE Agreement implements an "umbrella" agreement, The Agreement Concerning the Destruction of Silo Launchers of Intercontinental Ballistic Missiles, Emergency Response, and the Prevention of Proliferation of Nuclear Weapons, Dec. 13, 1993, U.S.-Kaz., 1993 WL 642422, extended Dec. 5, 2000 (on file with author). The DoD is the executive agent for the United States for activities under the umbrella agreement.

${ }^{16}$ WMDIE Agreement, supra note 15, at Annex A, Art. I, para. 1 (on file with author). 
It is in Uzbekistan, however, that the DoD has made perhaps the most notable progress since September 11th. After years of analysis and preliminary talks, but within just weeks of the September terrorist attacks on the United States, the DoD and the Uzbekistan Ministry of Defense signed an agreement to dismantle and demilitarize the BW infrastructure on Vozrozhdeniye Island and to help Uzbekistan prevent proliferation of BW technology and dangerous pathogens. ${ }^{17}$ This agreement was viewed as particularly timely in light of the fact that some of the anthrax buried at Vozrozhdeniye was a highly virulent strain with thick protective capsules resistant to most common antibiotics, qualities that made it an ideal target for theft by terrorists: "Federal officials feared that al Qaeda terrorists from neighboring Afghanistan might be able to obtain viable anthrax spores from the soil of the island ... avoiding some of the technical hurdles involved in developing a weaponized strain of anthrax. ${ }^{18}$ Administration officials noted that this agreement and a number of other U.S. government efforts together "reflect President Bush's determination to bolster the nation's biological warfare defenses in the wake of a spate of letters containing anthrax spores." ${ }^{19}$ Other commentators noted that although the focus in times of crisis tends to be on havoc and fear, the agreement with Uzbekistan could be viewed as a "collateral benefit. ${ }^{20}$ Moving quickly to begin dismantling the BW infrastructure and eliminate pathogens at Vozrozhdeniye, the DoD is now hoping to expand the BWPP program to Georgia and Ukraine.

Thus, while the United States has been criticized for rejecting the draft BWC protocol, the events of September 11 and the subsequent anthrax letter attacks in the United States have focused more attention on other effective measures the U.S. government is undertaking, including increased bilateral efforts to dismantle the BW legacy of the former Soviet Union. These accelerated efforts, which include assistance in dismantling and demilitarizing former production and research facilities, programs to consolidate, control and secure dangerous pathogens, and collaborative research to prevent the proliferation of BW-related expertise, are part of a growing, proactive, and targeted bilateral BW nonproliferation strategy. This proactive bilateral strategy, which is only part of the U.S. government's efforts in this area, contrasts with the difficulties and frustrations experienced by the United States in its efforts to promote implementation of effective multilateral measures to counter the threat posed by biological weapons.

\footnotetext{
${ }^{17}$ Agreement Between the Department of Defense of the United States and the Ministry of Defense of the Republic of Uzbekistan Concerning Cooperation in the Area of Demilitarization of Biological Weapons Associated Facilities and the Prevention of Proliferation of Biological Weapons Technology, Oct. 22, 2001, U.S.-Uzb., 2001 UST Lexis 57. This agreement implements the umbrella Agreement Concerning Cooperation in the Area of the Promotion of Defense Relations and the Prevention of Proliferation of Weapons of Mass Destruction, June 5, 2001, U.S.-Uzb., 2001, 2001 UST Lexis 32. The DoD is the executive agent for the United States for activities under the umbrella agreement, which was the first agreement signed by Colin Powell as secretary of state.

${ }^{18}$ Jonathan B. Tucker, How to Regulate The Trade in Toxins, N.Y. TIMES, Oct. 26, 2001, at A23.

${ }^{19}$ Judith Miller, A Nation Challenged: Spores; U.S. Agrees to Clean Up Anthrax Site in Uzbekistan, N.Y. TIMES, Oct. 23,2001 , at B1.

${ }^{20}$ Serge Schmemann, A Nation Challenged: An Overview: Oct. 21; More Deaths, More Questions, More Bombs, N.Y. TimES, Oct. 23, 2001, at B1.
} 